\title{
Methionine-Enkephalin Inhibits Stress-Induced Increases in Noradrenaline Turnover in Brain Regions of Rats
}

\author{
Masatoshi TANAKA, Akira TSUDA, Yoshishige IDA, Itsuko USHIJIMA*, \\ Shusaku TSUJIMARU and Nobuyuki NAGASAKI \\ Department of Pharmacology, Kurume University School of Medicne, \\ Kurume 830, Japan \\ *Department of Neuropsychiatry. Yamaguchi University School of Medicine \\ Ube 755, Japan
}

Accepted October 20, 1984

\begin{abstract}
Met-Enkephalin injected i.c.v. attenuated stress-induced increases in levels of 3-methoxy-4-hydroxyphenylethyleneglycol sulfate, the major metabolite of brain noradrenaline, in the hypothalamus, amygdala, hippocampus, thalamus, midbrain and LC region in rats. The data suggest that Met-enkephalin acts to attenuate stress-induced increases in noradrenaline turnover in these brain regions in rats.
\end{abstract}

By measuring the levels of noradrenaline (NA) and 3-methoxy-4-hydroxyphenylethyleneglycol sulfate (MHPG-SO ${ }_{4}$ ) which is the major metabolite of rat brain NA and indicative of brain NA turnover (1), we have reported that naloxone enhances and morphine attenuates stress-induced increases in NA turnover in several brain regions in rats $(2,3)$. From these results, it is hypothesized that endogenous opioid peptides released during stress are partly involved in the stress process by attenuating stressinduced increases in NA turnover in rat brain regions, especially in the hypothalamus and amygdala (3). In order to confirm this hypothesis, one such opioid peptide, methionineenkephalin (Met-enkephalin) injected intracerebroventricularly (i.c.v.), was investigated with regard to its effects on stress-induced increases in MHPG-SO $\mathrm{SO}_{4}$ level in six brain regions of rats.

Male Wistar rats $(170-200 \mathrm{~g})$ were anesthetized with pentobarbital and implanted with a polyethylene cannula into a lateral ventricle 4 days before the experiment began. Met-Enkephalin (Wako Pure Chemical Industries, Ltd.) at $100 \mathrm{~kg}$ and $200 \mathrm{\mu g}$ (dissolved in $5 \mu$ l of saline) per rat was used. These doses produce an analgesic action in rats (4) and in mice (5). Immediately after an i.c.v. injection with either saline $(5 \mu l)$ or an appropriate dose of Met-enkepahlin, the rats were stressed by immobilization within a wire mesh for $1 \mathrm{hr}$. Control animals were injected i.c.v. with saline $1 \mathrm{hr}$ before sacrifice. Immediately after each treatment, the rats were sacrificed by decapitation. The brain was dissected into discrete regions according to the method of Gispen et al. (6) and frozen on solid $\mathrm{CO}_{2}$. The locus coeruleus ( $\mathrm{LC}$ ) region was dissected by the method of Reis and Ross (7). Blood was collected from the cervical wound into heparinized tubes. Dissected tissues and separated plasma were stored at $-45^{\circ} \mathrm{C}$ until assayed. $\mathrm{MHPG}-\mathrm{SO}_{4}$ levels in the brain regions and plasma corticosterone levels were determined fluorometrically by the method developed by us (8) and by the method of van der Vies (9). respectively. For statistical analysis, Student's $t$-test (two-tailed) was employed.

One-hr immobilization stress caused significant elevations of $\mathrm{MHPG}-\mathrm{SO}_{4}$ levels in all brain regions examined as compared with those in saline control rats (Table 1), consistent with the previous reports wherein it was reported that increases in the metabolite levels are accompanied by reductions of NA contents in most regions examined $(2,3,10)$. These findings again indicate that NA 
Table 1. Changes in levels of 3-methoxy-4-hydroxyphenylethyleneglycol sulfate $\left(\mathrm{MHPG}-\mathrm{SO}_{4}\right)$ in the discrete brain regions and in plasma corticosterone levels in the rats stressed by immobilization for $1 \mathrm{hr}$ and their modifications by Met-enkephalin injected i.c.v. immediately before stress exposure

\begin{tabular}{|c|c|c|c|c|}
\hline & \multirow{2}{*}{$\begin{array}{l}\text { Saline } \\
\text { Control }\end{array}$} & \multicolumn{3}{|c|}{ Immobilization stress with } \\
\hline & & Saline & $\begin{array}{l}\text { Met-Enkephalin } \\
100 \mu \mathrm{g} / \mathrm{rat}\end{array}$ & $\begin{array}{l}\text { Met-Enkephalin } \\
200 \mu \mathrm{g} / \mathrm{rat}\end{array}$ \\
\hline \multicolumn{5}{|c|}{ MHPG-SO $\mathrm{S}_{4}$ Levels (ng/g) } \\
\hline Hypothalamus & $221.1 \pm 17.13$ & $480.1 \pm 26.52^{a * * *}$ & $404.6 \pm 21.19 \mathrm{~b}^{*}$ & $400.0 \pm 23.75^{b^{*}}$ \\
\hline Amygdala & $212.0 \pm 13.75$ & $280.0 \pm 20.55^{\mathrm{a} *}$ & $224.1 \pm 13.37^{b *}$ & $235.9 \pm 13.59 b^{*}$ \\
\hline Hippocampus & $173.3 \pm 9.33$ & $240.1 \pm 7.82^{* * * *}$ & $189.7 \pm 9.27^{b^{* * *}}$ & $183.6 \pm 7.74^{b^{* * *}}$ \\
\hline Thalamus & $228.7 \pm 14.17$ & $339.2 \pm 14.73^{\mathrm{a} * *}$ & $289.3 \pm 12.13^{\mathrm{b} *}$ & $232.3 \pm 17.19 b^{* * *}$ \\
\hline Midbrain & $205.6 \pm 10.32$ & $275.3 \pm 8.83^{a * * *}$ & $242.9 \pm 8.75^{b^{*}}$ & $240.7 \pm 11.68^{b *}$ \\
\hline LC Region & $294.8 \pm 17.83$ & $450.6 \pm 19.31^{\mathrm{a} * *}$ & $355.4 \pm 27.14^{\mathrm{b}}$ & $404.2 \pm 13.15$ \\
\hline $\begin{array}{l}\text { Plasma Corticosterone } \\
\text { Levels }(\mu \mathrm{g} / \mathrm{dl})\end{array}$ & $16.1 \pm 2.39$ & $46.7 \pm 3.12^{\mathrm{a} * * *}$ & $43.7 \pm 2.59$ & $42.9 \pm 1.17$ \\
\hline
\end{tabular}

Each value indicates the mean \pm S.E.M. of 8 rats. Statistical significance: a: vs. saline control and $b$ : vs. stress with saline. ${ }^{*} \mathrm{P}<0.05,{ }^{*} \mathrm{P}<0.01,{ }^{* *} \mathrm{P}<0.001$

turnover in these regions is enhanced by immobilization stress.

Both $100 \mu \mathrm{g}$ and $200 \mu \mathrm{g}$ of Met-enkephalin injected i.c.v. significantly attenuated the increases in MHPG-SO ${ }_{4}$ levels induced by immobilization stress in all brain regions examined with the exception of the LC regions, wherein the increases were significantly attenuated by Met-enkephalin at $100 \mu \mathrm{g}$ and marginally $(P<0.10)$ attenuated by Met-enkephalin at $200 \mu \mathrm{g}$. These findings suggest that Met-enkephalin acts to attenuate stress-induced increases in NA turnover in the six brain regions examined. The fact that Met-enkepahlin applied iontophoretically to the LC area produces inhibition of firing rates of some cells in this area (11) supports the present finding that Met-enkephalin attenuates stress-induced increases in NA turnover in the LC region as well as other brain areas. These attenuating effects of Met-enkephalin, however, did not occur in a dose-dependent manner, with the exception of the thalamus. The reason for this phenomnenon is uncertain; however, one possible explanation is that the dose range of Met-enkephalin used in the present study is not sufficient to differentiate the drug action on noradrenergic neurons, in particular, in the brain of stressed rats. This is likely, since both $3 \mathrm{mg} / \mathrm{kg}$ and $6 \mathrm{mg} / \mathrm{kg}$ of morphine injected subcutaneously also attenuate these increases in MHPG-SO $\mathrm{SO}_{4}$ levels induced by stress: however, they fail to show a doseresponse relationship (3).

Immobilization stress caused significant elevations of plasma corticosterone levels: however, neither dose of Met-enkephalin affected these increases (Table 1).

Recently, we have found that Metenkephalin injected i.c.v. in non-stressed rats, in contrast to stressed animais, increases MHPG-SO $\mathrm{SO}_{4}$ levels in the hypothalamus, amygdala, hippocampus and midbrain ( $M$. Tanaka et al., unpublished observation). The present results are thus in complete agreement with the previous findings that morphine injected s.c. also attenuated stress-induced increases in MHPG-SO ${ }_{4}$ levels in these brain regions, whereas morphine increased the metabolite levels in non-stressed rats (3).

Interestingly, in spite of the short duration of Met-enkephalin action, the present study revealed that Met-enkephalin injected i.c.v. $1 \mathrm{hr}$ before decapitation was still effective. It may be that the peptide acts on the site which causes serial, long-lasting changes in the organism.

In conclusion. Met-enkephalin, one of the opioid peptides existing in the mammalian brain, acts to attenuate immobilization-stressinduced increases in NA turnover in several brain regions, in particular, the hypothalamus. amygdala and hippocampus, which are closely related to emotionality in animals. This effect is similar to that observed with 
morphine. This result raises the possibility, supporting our view $(2,3)$ and that of Redmond and Huang (12), that enhancement of NA release by stress in these brain regions and its attenuation by Metenkephalin might be related to the regulation of "emotion" in animals exposed to stress. However, the present study is a preliminary one, and further studies on other opioid peptides, including the behavioral studies, would be needed to confirm this hypothesis.

Acknowledgements: We are grateful to Ms. S. Takeda for her technical assistance and to Dr. G.B. Glavin, the Department of Psychology. The University of Winnipeg. Manitoba, Canada, for his kind correction of the first draft of this manuscript. This work was partly supported by the Ministry of Education Grant-in-Aid for Scientific Research to M. Tanaka ( $\$ 58570109$ and $\$ 59570093)$.

\section{References}

1 Schanberg, S.M., Schildkraut, J.J., Breese, G.R. and Kopin, I.J.: Metabolism of norepinephrine$\mathrm{H}^{3}$ in rat brain-Identification of conjugated 3methoxy-4-hydroxyphenylethyleneglycol as the major metabolite. Biochem. Pharmacol. 17. 247-254 (1968)

2 Tanaka, M., Kohno, Y., Nakagawa, R., Ida, Y., limori, K., Hoaki, Y., Tsuda, A. and Nagasaki, N.: Naloxone enhances stress-induced increases in noradrenaline turnover in specific brain regions in rats. Life Sci. 30, 1663-1669 (1982)

3 Tanaka, M., Kohno, Y., Tsuda, A., Nakagawa, R., Ida, Y., limori, K., Hoaki, Y. and Nagasaki, N.: Differential effects of morphine on noradrenaline release in brain regions of stressed and nonstressed rats. Brain Res. 275, 105-115 (1983)

4 Belluzi, J.D., Grant, N., Garsky, V., Sarantakis,
D., Wise, C.D. and Stein, L.: Analgesia induced in vivo by central administration of enkephalin in rat. Nature 260, 625-626 (1976)

5 Ueda, H., Amano, H., Shiomi, H. and Takagi, H.: Comparison of the analgesic effects of various opioid peptides by a newly devised intracisternal injection technique in conscious mice. Eur. J. Pharmacol. 56, 265-268 (1979)

6 Gispen, W.H., Schotman, P. and de Kloet, E.R.: Brain RNA and hypophysectomy: A topographycal study. Neuroendocrinology 9, 285296 (1972)

7 Reis, D.J. and Ross, R.A.: Dynamic changes in brain dopamine- $\beta$-hydroxylase activity during anterograde and retrograde reactions to injury of central noradrenergic axons. Brain Res. 57, 307-326 (1973)

8 Kohno, Y., Matsuo, K., Tanaka, M., Furukawa, T. and Nagasaki, N.: Simultaneous determination of noradrenaline and 3-methoxy-4-hydroxyphenylethyleneglycol sulfate in discrete brain regions of the rat. Anal. Biochem. 97, 352-358 (1979)

9 Van der Vies, J.: Individual determination of cortisol and corticosterone in a single small sample of peripheral blood. Acta Endocrinol. 38, 399-406 (1961)

10 Tanaka, M., Kohno, Y., Nakagawa, R., Ida, Y., Takeda, S., Nagasaki, N. and Noda, Y.: Regional characteristics of stress-induced increases in brain noradrenaline release in rats. Pharmacol. Biochem. Behav. 19, 543-547 (1983)

11 Young, W.S., III, Stephanie, B.J. and Kuhar, M.J.: Iontophoresis of methionine-enkephalin in the locus coeruleus area. Brain Res. 129, 366370 (1977)

12 Redmond, D.E., Jr. and Huang, Y.H.: Current concept. II. New evidence for a locus coeruleusnorepinephrine connection with anxiety. Life Sci. 25, 2149-2162 (1979) 